УДК 811.161.2'373:159.942

Т. І. Вавринюк

\title{
ЕКВІВАЛЕНТИ РЕЧЕНЬ ЯК ЗАСОБИ ЕКСПРЕСИВНОГО СИНТАКСИСУ В ХУДОЖНЬОМУ ТЕКСТІ
}

Вавринюк Т. І. Еквіваленти речень як засоби експресивного синтаксису в художньому тексті.

У статті йдеться про еквіваленти речень як про засоби експресивного синтаксису. Увагу звернено на різні модальні типи слів-речень, на незакінчені речення та звертання-речення. Обгрунтовано думку, що синтаксичні експресивні засоби відзначаються художньо-зображальною місткістю, здатністю відображати широкий діапазон модальних значень, відтворювати емоційний стан героїв художнього твору.

Ключові слова: експресивний синтаксис, слова-речення, незакінчені речення, звертання-речення.

Вавринюк Т. І. Эквиваленты предложений как средства экспрессивного синтаксиса в художественном тексте.

В статье рассматриваются средства экспрессивного синтаксиса. Внимание уделено разным типам слов-предложений, прерванным предложениям, вокативам. Обоснована мысль, что синтаксические экспрессивные средства отличаются художественно-изобразительной вместимостью, способностью отображать широкий диапазон модальных значений, отображать эмоциональное состояние героев художественного произведения.

Ключевые слова: экспрессивный синтаксис, слова-предложения, прерванные предложения, вокатив.

Vavryniuk T. I. Equivalents of sentences as means of expressive syntax in the literary text. 
The article refers to the equivalents of sentences as means of expressive syntax. Attention is drawn to the various modal types of word-sentences, incomplete sentences and address sentences. It is determined that equivalents of sentences in the context of a literary text often operate in the style of verbal-colloquial speech dialogs. It is investigated expressive functions of the affirmative, negative, interrogative, incentive, emotionallyevaluative, and word-sentences of the speech etiquette. It is substantiated the view that the amplification word-sentences creates emphatically intone, sensory intense complex of statement that allows author to organically include the subjective world of characters into his narrative. It is revealed that unfinished sentences are the means of recreation certain emotional states of the characters (confusion, despair, hesitation, grief, indecision, delight, joy, determination, etc.). Vocative sentences or address sentences are highlighted among the expressive means, emotional tone of which is provided by special intonation. It is revealed that that the main meaning of these not divisioned communiques is incentive, addressed to the person to whom appeal. Units with distinct incentive action are highlighted among the address sentences, which realize modal meaning in literal speech (the order, request, reservations, etc.) through context. It is proved that address sentences combine appeal and expressive features, can express not only address to the recipient, but also the attitude of the speaker to it. It is concluded that syntactical expressive means distinguished by artdescriptive figurative capacity, the ability to display a wide range of modal values, reproduce the emotional state of the characters of artistic composition.

Key words: expressive syntax, word-sentences, incomplete sentences, address sentence.

Засоби експресивного синтаксису сьогодні перебувають у зоні посиленої уваги дослідників мови творів художньої літератури. Адже експресивність - визначальна риса художнього стилю, важливий засіб впливу на читача. Утілюючи думку в синтаксичну структуру, автор повідомлення неминуче передає і своє ставлення до того, про що йде мова, а отже, саме на рівні синтаксису виявляється якнайповніше авторська позиція - експресивність постає як феномен мовної особистості та ії суб'єктивних інтенцій.

Теорія експресивного синтаксису, яку започаткував Ш. Баллі, нині активно розробляється такими українськими вченими, як Н. Гуйванюк, С. Єрмоленко, А. Загнітко, Н. Івкова, В. Чабаненко.

В. Чабаненко розмежував поняття експресія та експресивність: «Якщо експресія - це інтенсифікація (збільшення, підсилення) виразності, то екпресивність - це вже сама інтенсифікована (збільшена, підсилена) виразність, така психологічно й соціально мотивована властивість мовного знака, що деавтоматизує його сприйняття, що () Т. І. Вавринюк, 2016. 
підтримує загострену увагу, активізує мислення людини, викликає напругу почуттів у слухача (читача) <..> На наш погляд, «експресивниий» треба розуміти як «інтенсифіковано (збільшено, підсилено) виразний» [8, с. 7]. Отже, засоби експресивного синтаксису - це такі синтаксичні структури, які відзначаються інтенсифікованою виразністю. Саме ця властивість дозволяє цим структурам не лише виражати думку про дійсність, а й прямо чи опосередковано давати оцінку цій дійсності.

А. Загнітко вважає, що «кваліфікація синтаксичних конструкцій 3 погляду експресії як спеціального прийому залежить: 1) від форми мовлення; 2) функціональної спрямованості мовлення», а проблему експресивного в синтаксисі слід пов'язувати насамперед iз проникненням усно-розмовних тенденцій у писемну практику [3, с. 140].

Відображенням усно-розмовних тенденцій у контексті художнього твору $\epsilon$ так звані еквіваленти речення, які містять величезний експресивний потенціал. Докладно описав ці одиниці П. Дудик, який виокремив 3-поміж них слова-речення, незакінчені речення та звертання-речення, указавши при цьому, що функціонують ці одиниці «як повноправні виражальні засоби мови, що сприймаються на синтаксичному рівні речення як його своєрідні замінники [2, с. 289]. Оскільки ці відносно незалежні висловлення виділяють в основному на підставі комунікативного функціонування, то автори посібника «Синтаксис сучасної української мови: Проблемні питання» вважають, що названі типи одиниць «точно було б назвати комунікатами» [7, с. 286]; А. Загнітко використовує термін «квазі-речення» і відносить до них речення-звертання (вокативи), вигукові речення, речення-репліки, а також близькі до них формулоподібні речення метакомунікативної настанови [4, с. 63].

Попри відмінності в термінології вчені сходяться втому, що ці структури є своєрідними замінниками речення, його еквівалентами, оскільки вони не диференціюються на члени речення або ж 
становлять незакінчену частину речення чи характеризуються підтекстом, реалізація якого може бути різною.

Слова-речення в контексті художнього твору найчастіше функціонують у стилізованих під уснорозмовне мовлення діалогах. Ці речення можуть виражати ствердження, заперечення, запитання, спонукання, емоційну оцінку тощо. Залежно від цього виокремлюють стверджувальні, заперечні, питальні, спонукальні, емоційно-оцінні, слова-речення у функції структур мовного етикету.

Так, стверджувальні чи заперечні слова-речення набувають експресивності, коли передають емоційну реакцію мовця на висловлення співрозмовника. Наприклад:

- Ти документи Івана Степановича...

- Taк! (1, с. 123);

- Ми тут живемо.

- Ні! - розсміялася. - Тут живу я! (1, с. 21);

Хлопецьь чекав біля клубу. Сидів на кованій огорожі, на колінах розкладена махова дошка. Фігури на стартових позичіях.

- Ні! - мотнула головою Люда. - Навіть не проси! Мені в академію...

- Могилянка?

- Так! - гордо (1, с. 76).

Оклична інтонація надає словам-реченням інтенсифікованої виразності, що допомагає відтворити емоційний стан мовця.

Слово-речення Угу, крім стверджувального модального значення, може передавати приховані інтенції мовця, наприклад, небажання вступати в діалог, певну відстороненість:

Малий сидить біля монітора... Вісімнадиять років, периий курс політехнічного, а «Малий»- це за дурнуватою батьківською звичкою.

- Добрий вечір! - мацуаю його за плече.

- Мама хвилюється, изо ти багато сидии за комп 'ютером.

- Угу, - киває він.

От і поговорили. 
- Ти вечеряв?

- Угу, - він не відривається від монітора, клачаючи одночасно двома руками (5, с. 24).

У ролі стверджувальних слів-речень можуть виступати слова на зразок точно, добре, правда, геніально тощо, які в цій функції хоч і зазнають часткової асемантизації, однак зберігають за собою властивість експресивно виражати різні відтінки стверджувальної модальності:

а) цілковитої згоди із співрозмовником:

- Твій хід!

- Добре! - закурив (1, с. 78);

- Та для неї тут усе - однакова ахінея.

- Точно (5, с. 37);

б) згоди 3 позитивною емоційною оцінкою співрозмовника, яка забезпечується інгерентною експресивністю відповідних лексем:

- ... ти, Серьога, повинен одразу до мене звертатися напряму. I стільки разів, скільки буде потрібно. Бо інакше кожен мій заступник може стати головнішим за мене.

- Геніально! - резюмував Павлюк-паша.

- Потужно, - додав генерал (5, с. 39).

Посилює експресію заперечення, надає йому категоричності прийом редуплікації, сутність якої як стилістичного засобу полягає насамперед у посиленому впливі на читача, оскільки будь-який повтор виконує функцію виокремлення, підкреслення, передає емоції:

- Дєвушка, да успокойтесь ви! - бурчать у черзі.

- Hi-ні, почекайте! (6, с. 37);

- Так, - каже Марта Богданівна. - це моє рішення. Я не можу більше з тобою жити.

- Hi. Hi. Hi! (6, с. 152);

Ірма Іванівна виймає з-під прилавка пачку сигарет $i$ одну запалює.

- Ти не хочеш, Жанка?

- Нє-нє, я не курю (6, с. 250). 
В останньому прикладі - просторічний варіант заперечення, який є засобом індивідуалізації мовлення літературного персонажа, а повтор виступає засобом інтенсифікації впливу на співрозмовника.

Особливою експресивністю відзначаються стверджувальні й заперечні слова-речення у складі невласне прямої мови, за допомогою якої відтворюється внутрішнє мовлення певного літературного героя:

Ретельно вивчає схему метрополітену на віконці каси.

Республіканський стадіон»? Hi. «Дружби народів»? Нi. Може, «Печерська»? «Контрактова площуа»? «Петрівка»? Всюди $\epsilon$ «б» $i$ «р». Брр.

«Львівська брама»? «Львівська брама»! Точно (6, с. 4).

Слова-речення у структурах невласне прямої мови, підкреслені психологічною паузою (на письмі вона передається двокрапкою), один із засобів відтворення афектного стану персонажа:

Очі. Дуже виразні очі. Очі розумної людини. Може виграти? $\mathrm{Hi}$ фіга! Вона не піддасться... (1, с. 77);

Макс здригнувся. Померла? Ні... Не було такого слова. Не померла. Мама взагалі вважає, щзо жива. Не померла (1, с. 183).

Питальні слова-речення $є$ комунікативними одиницями художнього діалогу, що моделюється за зразком діалогу ситуативного:

- Я вам не довіряю.

- Даремно.

- Хіба? (6, с. 137).

У діалогах слова-речення питальної модальності можуть передавати різні емоційно-експресивні відтінки. Виконуючи роль репліки-прямого питання, такі слова-речення забезпечують розгортання діалогу. Наприклад:

- Я подумав, може, я проведу вас додому?

- Навіщцо?

- Поговоримо по дорозі.

- Про щцо?

- Придумаємо (6, с. 130); 
- От навіщзо ти себе так ведеш, Антоніна?

- Як? (6, с. 133);

Питальне слово-речення може виступати своєрідним підхопленням незакінченої репліки співрозмовника і стимулювати останнього до продовження думки, яку він з якихось міркувань не наважувався висловити. Наприклад:

- А шуо конкретно треба буде робити?

- Виловлювати з акваріума живу рибу і...

- I..?

- І відрізати їй голову (6, с. 4);

- Але в мене є для вас пропозиція, - Антоніна Василівна хвильку роздумує. - Я дозволю вам вмикати музику, якщео...

- Якщио?

- Якщуо ви дозволите мені приходити і дивитися (6, с. 111).

Експресивність тексту посилюється, якщо питальні словаречення об'єднуються у структурно-смислову єдність 3 іншими експресивно маркованими типами питальних речень. Наприклад:

Голова обертом. Погнав до центру... Холодний розум, як майстерний фотограф, підкинув об’єктивні кадри минулої ночі, залишивии простір істеричним емоціям. I щио тепер? Що тепер? Як він без неї?.. І вже не «чому?», а «за щио?!».

- За що мені все це? За що? - кулаком по керму (6, с. 142);

- І де він? Де він зараз? - наступала мати.

- Я йому номер у готелі зняв.

- Навіщи? (6, с. 111).

Ампліфікація питальних речень створює емфатично інтонований, почуттєво напружений комплекс вислову, що дозволяє авторові суб'єктивний світ героїв органічно ввести в свою оповідь.

Спонукальні слова-речення у досліджених творах виконують здебільшого пряму функцію спонукання до дї, наприклад:

$-\boldsymbol{H y}$ ?

- Що ну?! - уточнив я (6, с. 3); 
Вона блиснула очима:

- Я не вважаю. Я знаю. Подивися банківські виписки.

$-\boldsymbol{H y}$ ? (5, c. 115).

Оскільки оформлювачами спонукальних слів-речень виступають вигуки та функціонально близькі до них слова, то ці одиниці відзначаються особливою емоційністю, надають художньому діалогу розмовного колориту. Наприклад:

- Гей! - зойкнув. Відштовхнув білявого. - Ти щзо за такий (1, с. 6).

Емоційно-оцінні слова-речення містять у собі безпосередню реакцію мовця на те, що відбувається чи говориться, і передають різні емоційні стани літературних героїв (занепокоєння, досаду, радість, захоплення, тощо). Наприклад:

Дерева знов загомоніли. Білявий вишкірився:

- A-a-a-a, диявольські діти. По мене прийшли? Хочете сина християнського під собою мати?! (1, с. 6);

- Отакої! Товаришам розповісти, не повірили б - щоби біля раю бути і згинути через кума і якусь дурну дівку (1, с. 11);

- Ой! - розсміялася Люба (1, с. 27);

- Ого! Та він крутий! - Макар (1, с. 41);

Експресивно-модальні значення вигуків у репліках художнього діалогу конкретизуються авторськими словами або ж ці значення обумовлюються контекстом. Найбільш уживаними в ролі емоційнооцінних вигукових слів-речень виступають сполуки 3 компонентами Боже, Господи тощо. Наприклад:

- Боже, - шепоче Марта Богданівна, - о боже (6, с. 153);

О боже, щзо я виговорюю, думає Антонініа Василівна (6, с. 120); - Матінко Божа... - Микитка зачаровано. - Та иее ж Київ... $(1$, c. 7$)$;

Розгублено озирнувся...

- Господи...(1, с. 114).

Як засоби експресивного синтаксису в контексті художнього твору розглядаємо також слова-речення, що виконують функцію 
мовного етикету. Це синтаксично нечленовані побудови, які становлять традиційні i загальноприйняті формули привітання, прощання, вибачення, подяки, побажання успіхів тощо. Наприклад:

- Любо... Привіт! - так просто і так невимушено, ніби сто років знайомі.

- Привіт, - усміхнулася (1, с. 79);

- Доброї ночі, - знову. - Чуєш, синку... Оче справи до Києва за шкіру притягли. Часом не підкажеш... Та ні! Спочатку скажи звати як? (1, с. 11);

- Вітаю, - потис дядькову долоню, назвався: - Сердюк Володимир Гнатович. Народний депутат Украӥни (1, с. 120);

- Тьху ти, яка біда! Вибачте, вибачте, їй-богу, - розстроївся дядько (1, с. 120);

- Завтра, як завжди? - запитує він, відсміявшись

- Авжеж. Добраніч.

- Щасти вам (5, с. 22).

Особливою експресивністю відзначаються незакінчені (перервні, обірвані) речення - структури, які виражають перервані, до кінця не висловлені думки. Як зауважує П. Дудик, «так звані незакінчені речення являють собою початкові частини звичайних речень - простих «самостійних», складносурядних і складнопідрядних [3, с. 303]. Змістова, структурна та інтонаційна незакінченість цих структур зумовлена емоційним станом мовця. Наприклад:

- Що за... - тремтячою рукою по чолу. - Що за... (1, с. 12).

- Так. Зима... це холодно... але до зими ще... - боронився (1, c. 16).

Незакінчені речення здебільшого $є$ ознакою схвильованого мовлення, а в художньому тексті вони є засобом відтворення певних емоційних станів персонажів (розгубленість, відчай, вагання, горе, нерішучість, захоплення, радість, рішучість тощо). Наприклад:

- Любо... Ти...

- Не... сьогодні, - ледь змогла (1, с. 82); 
- Нема чого?.. - Макс раптом зблід. Божевільними очима зміряв мати. Усміхнувся недобре. - А Люба... Як жее люба? Треба ж⿻.. Тіло знайти. Батьків повідомити. По...ховати. Крім мене ніхто не знає, щуо з нею сталося. Ти розумієш? І я... Я мовчу. Це жс.. I ти ... Ти навіть не жахнулася, що загинула людина... Годуєш мене якоюсь маячнею про дебілів... А треба ж... - забігав, за голову схопився. Господи, Господи...(1, с. 145).

До експресивних засобів також належать вокативні речення. Основним змістом цих нечленованих комунікатів $є$ спонукання, адресоване особі, до якої звертаються. Наприклад:

- Батьку!

- Слухаю (5, с. 25);

- Да, так вот. Шановний панЕ СергіЮ! - він був явно задоволений вдалим застосуванням складного кличного відмінка $(5$, c. 11$)$;

- Антоніна Василівна! Що ви робите?! Ви переїљджаєте? двірничка Леся якраз підмітає асфальтовану доріжку перед під '̈здом (6, с. 140).

Вокативні речення завжди модально й емоційно забарвлені, i «це виявляється у своєрідній інтонації, яка не цілком збігається 3 інтонацією звичайного звертання, оскільки нею передається ширше значення і складніше уявлення» [4, с. 66].

Ці одиниці можуть виражати заклик, прохання чи вимогу відповісти, відгукнутися тощо. У ролі звертань-речень здебільшого виступають власні особові назви або їх апелятиви. Наприклад:

- Любо! - гукнув Макс із салону.

Не почула (1, с. 53);

- Галко! Хіба до Десни вниз за течією? (1, с. 162);

- Хлопці! Хлопці! - загорлав (1, с. 56).

Серед звертань-речень виділяються одиниці 3 виразною спонукальною дією, які в в художньому мовленні реалізують модальне значення (наказу, прохання, застереження тощо) через 
контекст. Зауважимо, що в уснорозмовному діалозі всі відтінки модальних значень передаються інтонацією. Наприклад:

- Марто! Зустрінь клієн... шановного Івана Степановича! (1, с. 114) - наказ;

- Георгію Ісаковичу! Тут у мене людина пропала. Може, хтось із ваших знає, де ії иукати? (5, с. 324);

- Ну, Сергію! Це вже не жарти! (5, с. 267).

Емоційно-експресивними центрами художніх діалогів $\epsilon$ звертання-речення, які виражають особливе ставлення до співрозмовника. Наприклад:

Із такими підбадьорливими думками Ліда постукала у двері.

- Любочко! Ти вдома, дитино?! (1, с. 24);

- Я ї̈ на шматки порву! - визвірився Гоцик, а Макар уже підхопився громити жирних.

- Ні, братчики ... Не треба, - безпорадно (1, с. 29);

Люба... розсміялася:

- Гей, голото, братчики...Чуєте? - молола. - Макарчику! Гоцику, слоняро! Та прокидайтеся, вар'яти падлючі! (1, с. 41).

Окремі вокативні речення вирізняються яскраво вираженою емоційністю, унаслідок чого значення спонукання дещо послаблюється:

- Куме? - прошепотів. Як заверешить: - Куме! Куме Микишко! Невже ти? Пресвята Богородице небесна, $i$ Ти, святий Боже єдиний! Куме! [1, с. 7].

Відображаючи емоційно-вольову сферу мовця, звертанняречення поєднують апелятивну й експресивну функції, можуть виражати не лише звернення до адресата, а й ставлення з боку мовця до нього. Експресивність забезпечується особливою інтонацією цих одиниць. У комплексі всі еквіваленти речень $є$ засобами експресивного синтаксису, які сприяють смисловій конденсації й логічному увиразненню думки, розставляють акценти на важливих елементах художнього тексту, увиразнюють експліцитно виражений зміст, породжують певний тон мовлення, «заряджають» емоціями читача. 


\section{Література}

1. Дашвар Люко. РАЙ. Центр / Люко Дашвар. - Х. : Клуб Сімейного Дозвілля, 2010. $-272 \mathrm{c}$.

2. Дудик П. С. Просте речення / П. С. Дудик // Сучасна українська літературна мова : Синтаксис / за заг. ред. І. К. Білодіда. - К. : Наукова думка, 1969. - 645 с.

3. Загнітко А. П. Основи українського теоретичного синтаксису / А. П. Загнітко. Ч. 3. - Горлівка : ГДППМ, 2004. $-266 \mathrm{c.}$

4. Загнітко А. Український синтаксис: теоретико-прикладний аспект / А. Загнітко. - Донецьк, 2009. - 137 с.

5. Капранови Брати. Щоденник моєї секретарки / Брати Капранови. - К. : Гамазин, 2011. $-400 \mathrm{c}$.

6. Малярчук Т. Звірослов / Т. Малярчук. - Х. : Фоліо, 2009. - 281 с.

7. Слинько I. I. Синтаксис сучасної української мови : Проблемні питання: [навчальний посібник] / І. І. Слинько, Н. В. Гуйванюк, М. Ф. Кобилянська. - К. : Вища школа, 1994. - $670 \mathrm{c}$.

8. Чабаненко В. А. Стилістика експресивних засобів української мови : [монографія] / В. А. Чабаненко. - Запоріжжя : ЗДУ, 2002. - 351 с.

Стаття надійшла до редакиії 29.09.2016 p. 